\title{
PECULIARITIES OF FREE-RADICAL PROCESSES AND NEUROPSYCHOLOGICAL STATUS IN PATIENTS WITH CHRONIC GENERALIZED PERIODONTITIS AND POSSIBILITY OF CORRECTING THEIR IMPAIRMENTS WITH ANTIOXIDANT THERAPY
}

Mihail Saulin ${ }^{1}$, Sergej Bolevich ${ }^{1}$, Tatjana Savateva-Liubiova ${ }^{2,3}$, Konstantin Sivak ${ }^{3}$, Ekaterina Silina ${ }^{1}$

${ }^{1}$ I.M. Sechenov First Moscow State Medical University, Moscow, Russia

${ }^{2}$ Institute of Toxicology of the Federal Medical and Biological Agency, St. Petersburg, Russia

${ }^{3}$ Smorodintsev Research Institute of Influenza, St. Petersburg, Russia

\section{KARAKTERISTIKE SLOBODNO-RADIKALSKIH PROCESA I NEUROPSIHOLOŠKOG STATUSA KOD PACIJENATA SA HRONIČNIM GENERALIZOVANIM PARODONTITISOM I MOGUĆNOST KOREKCIJE NJIHOVIH OŠTEĆENJA ANTIOKSIDATIVNOM TERAPIJOM \\ Saulin Mihail ${ }^{1}$, Bolevich Sergej ${ }^{1}$, Savateva-Liubiova Tatjana ${ }^{2,3}$, Sivak Konstantin ${ }^{3}$, Silina Ekaterina ${ }^{1}$ \\ ${ }^{1}$ I.M. Prvi Moskovski državni medicinski univerzitet Sečenov, Moskva, Rusija \\ ${ }^{2}$ Institut za toksikologiju Federalne medicinske i biološke agencije, Sankt Peterburg, Rusija \\ ${ }^{3}$ Smorodintsev Institut za istraživanje influence, Sankt Peterburg, Rusija}

\section{ABSTRACT}

This clinical study included a total of 71 patients with chronic generalized periodontitis (CGP). The chemiluminescence method was used to determine the level of generation of reactive oxygen species by leukocytes (basal and stimulated), as well as the content of malonic dialdehyde in blood plasma and antiperoxide activity of plasma. The anxiety level was measured using the Spielberger's test. Patients with chronic generalized periodontitis in the exacerbation phase were found to have a natural significant increase in both basal and stimulated PICL, as well as an increase in blood plasma malonic dialdehyde 1.6-, 3.9- and 1.4-fold, respectively, compared with apparently healthy donors (all p<0.05), and a significant 2.1-fold decrease in plasma APA compared with healthy donors $(p<0.001)$. In the remission phase, all parameters were normalized, however, they did not reach the norm. We revealed significant dependence of reactive oxygen species generation by leukocytes, lipid peroxidation and antiperoxide activity of plasma on the severity of the course of chronic generalized periodontitis, whereas plasma antiperoxide activity decreased. In patients with the severe course, after the treatment with $A O$, situational and personal anxiety increased, depression deteriorated, unlike patients with mild-to-moderate course in whom this symptomatology virtually disappeared. In patients with the severe course of periodontitis after surgical manipulations, the parameter in the Hounsfield units increased gradually, on days 14, 30 and 90 on average, 1.3 , 2.4 and 3.2-fold, respectively, thus suggesting that bone tissue density increased faster after surgical methods of treatment in patients with severe chronic generalized periodontitis.

Keywords: free radical processes, neuropsychological status, generalized periodontitis, antioxidant therapy.

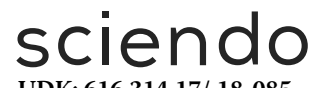

Ser J Exp Clin Res 2019; 20 (2): 55-64 DOI: 10.2478/SJECR-2019-0034

\section{SAŽETAK}

Ova klinička studija obuhvatila je ukupno 71 bolesnika sa hroničnim generalizovanim parodontitisom (HGP). Metod hemiluminescencije je korišćen za određivanje nivoa produkcije reaktivnih vrsta kiseonika posmatranjem leukocita (bazalnih $i$ stimulisanih), kao i sadržajem malonil-dialdehida i aktivnosti antiperoksidaze u plazmi. Nivo anksioznosti je meren korišćenjem Spilbergerovog testa. Pacijenti sa hroničnim generalizovanim parodontitisom u fazi egzacerbacije su naišli na prirodno značajno povećanje $i$ bazalnog $i$ stimulisanog parametra intenziteta hemiluminescencije, kao i povećanja malonil-dialdehida u plazmi 1,6-, 3,9 i 1,4 puta, u poređenju sa očigledno zdravim donatorima $(r<0,05)$, i značajno 2,1-struko smanjenje aktivnosti antiperoksida u plazmi $(A P A)$ u poređenju sa zdravim donorima $(r<0,001)$. $U$ fazi remisije, svi parametri su normalizovani, ali nisu dostigli normu. Otkrivena je značajna zavisnost reaktivnih vrsta kiseonika od leukocita, lipidne peroksidacije $i$ antiperoksidne aktivnosti plazme na težinu hroničnog generalizovanog parodontitisa, dokje aktivnost plazma antiperoksida smanjena. Kod bolesnika sa teškim tokom bolesti, nakon tretmana sa AO, situaciona $i$ lična anksioznost su se povećale, depresija se pogoršala, za razliku od pacijenata sa blagim do umerenim tokom, kod kojih je ova simptomatologija praktično nestala. Kod pacijenata sa teškim tokom parodontitisa nakon hirurških intervencija, parametar $u$ Hounsfield jedinicama povećavao se postepeno, u srednjim danima 14, 30 i 90, odnosno 1,3-, 2,4- i 3,2-puta, što ukazuje na to da je gustina koštanog tkiva povećana brže posle hirurških metoda lečenja kod pacijenata sa teškim hroničnim generalizovanim parodontitisom.

Ključne reči: slobodni radikali, neuropsihološki status, generalizovani parodontitis, antioksidativna terapija.

Corresponding author: Mihail Petrovich Saulin,
I.M. Sechenov First Moscow State Medical University, E-mail: mikhail-saulin@yandex.ru 


\section{INRODUCTION}

The treatment of inflammatory periodontal diseases is currently one of the important problems in dentistry. According to the $\mathrm{WHO}$, the incidence of periodontal diseases in people over 40 years old exceeds $95 \%$, with the diseases being aggressive and almost untreatable [7].

Currently, a large body of studies exists on periodontitis. However, despite improved surgical, therapeutic and prosthetic techniques, periodontal diseases have a steadily progressing course. Besides, the problem of priority of etiopathogenesis is still controversial.

The last several decades have seen extensive studies of free-radical processes whose role was proven in a wide variety of nosological entities. However, the number of studies addressing the state of oxidative stress in patients with periodontitis appears to be sparse.

Free-radical processes (FRPs) are known to be general biological mechanisms of defence and damage of tissues [11, 12]. In health, they participate in energetic processes, transport of electrons in the chain of respiratory mitochondria, proliferation and differentiation of cells, in regulation of enzyme activity, etc. Besides, FRP is an indispensable link of any inflammation, associated with production of reactive oxygen species (ROS) by phagocytes. This evolutionally developed secretory function of phagocytes is required for killing of bacteria; however, an abrupt increase of oxygen consumption during phagocytosis leads to the fact that instead of $\mathrm{O}_{2}$ reduction to $\mathrm{H}_{2} \mathrm{O}$ leukocytes mainly generate ROS. Overproduction of ROS initiates free-radical lipid peroxidation (LPO), which damages tissues, first of all, the biological membranes [2, 14]. The appearance of a large number of free radicals is associated with impaired transport of electrons in the mitochondrial chain; dissociation of oxidative phosphorylation under the effect of LPO leads to profound deficit of energy, accompanied and followed by changed functions of enzymes, carbohydrates and proteins, including proteins of DNA and RNA, with the resulting loss by the cell of its regulatory functions, accompanied by the emergence of abnormal proteins and stimulation, apart from a direct damaging effect, of secondary destructive processes. Deep disorders of the membranous and, consequently, total architectonics lead to cell death. This process is referred to as oxidative stress.

Given that a significant role in the etiopathogenesis of periodontitis is assigned to bacterial flora closely related to activity of free radicals and immune responses, FRPs are one of the links of the development and course of periodontitis.

In this connection, it appears appropriate and currently important to study the state of systemic free-radical homeostasis and assess prompt pathogenetically substantiated correction of oxidative stress reactions in patients with periodontal diseases. It served as the basis for carrying out the present study.

\section{PATIENTS AND METHODS}

This clinical study included a total of 71 patients [35 $(49.3 \%)$ men and $36(50.7 \%)$ women] suffering from CGP, aged from 17 to 77 (mean age $47.22 \pm 6.67$ years).

Once enrolled into the study, the patients were randomly divided into two groups. Group One (comparison group) comprised $32(45.1 \%)$ patients aged from 30 to 73 (mean age $44.79 \pm 6.35$ years) receiving conventional therapy including the standard set of surgical, therapeutic and prosthetic manipulations. Group Two (study group) was composed of 39 (54.9\%) patients aged from 28 to 76 (mean $51.22 \pm 7.92$ years). All patients from this group additionally received AO therapy [cytoflavin 1-2 tablets twice daily for 25 days, mexidole 1 tablet $(125 \mathrm{mg})$ three times daily and ascorbic acid 1 dragee (100 $\mathrm{mg}$ ) three timed daily] in the composition of conventional treatment. Eighteen $(16.7 \%)$ patients additionally received a calcium preparation (calcium $\mathrm{D}_{3}$ ), 1 chewing tablet twice daily for 30 days. The groups of patients were homogeneous and statistically did not differ.

The anxiety level was determined by means of the Spielberger's test [Spielberger C. D., 1966]. It was used to obtain tentative standards: low anxiety level $-20-24$ points, moderate level $-35-44$ points and high level -46 points and more. The total score was obtained by calculating the results with the help of the key taking into consideration inverted statements. The obtained data were processed in accordance with the software on an IBM PC. The test is an informative method of measuring the level of state anxiety at a given moment (reactive anxiety as a state anxiety about an event) and personal anxiety (trait anxiety as a personal characteristic). The selfassessment scale consists of two parts, separately evaluating reactive anxiety (items № 1-20) and personal anxiety (items № 21-40).

The dynamics of the anxiety state before and after treatment was assessed using the first half of the scale (statements № 1-20), whereas the dynamics of the therapeutic course was assessed by means of the second half of the scale (statements № 21-40).

Personal anxiety characterizes permanent proneness of people to perceive a wide range of situations as dangerous or threatening and to respond to such situations with elevations in the intensity of their state anxiety. Very high reactive anxiety induced impaired attention, sometimesimpaired fine coordination. Very high personal anxiety directly correlated with the presence of neurotic conflict, with emotional and neurotic breakdowns and with psychosomatic diseases.

In order to determine the normal value of CL of the parameters of GROSL we examined a total of 30 apparently healthy donors (12 men and 18 women). The donors' age varied from 19 to 57 years (mean $39.66 \pm 1.67$ years). 
Therapeutic policy in patients corresponded to the standards and included a set of surgical, therapeutic and prosthetic measures. All patients were subjected to removal of dental deposits, smoothing and polishing of the exposed root portion, immobilization of movable teeth by splinting. Local therapy consisted of mouth rinsing with antiseptics, applications on the mucous membrane of the gingival margin, and administration of anti-inflammatory agents to the periodontal pocket.

The patient's condition was assessed in dynamics (at admission, on days 14 and 30 of the therapy) based on a set of clinical, laboratory and instrumental methods: studying case history and complaints, examining of the oral cavity, gingival margin of the mucous membrane with the assessment of the degree of gingival edge recession and teeth motility, studying salivary total protein, alkaline phosphatase (ALP), MDA and catalase, blood plasma FRP by the GROSL values - a basal parameter of intensity of chemiluminescence (PICLb) and zymozan-stimulated chemiluminescence intensity (PICLs), by indices of plasma APA, MDA, X-ray picture based on orthopantomogram with analysis of reduction of the interalveolar septum height and the level of teeth root exposure, measuring periodontal pockets depth with a periodontal probe, periodontal index (PI), Fedorov-Volodkin hygiene index (HI), index of the degree of inflammatory events, gingivitis, papillary marginal alveolar index (PMA).

Chemiluminescent (CL) parameters of GROSL were examined using chemiluminescence-adapted luminometer LKB "Wallac" (Sweden) at the standard temperature of $36.9^{\circ} \mathrm{C}$.
We determined the level of the basal (spontaneous) CL in the standard volume of leukocyte suspension with the standard leukocytic concentration $(2500$ in $1 \mu \mathrm{l})$. After adding a nonspecific activator $(0.1 \mathrm{ml}$ of $1 \%$ zymosan solution) we determined PICLs. MDA, a secondary by-product of LPO, was determined according to the technique described by Douest J.C. (1983). The methodology of studying plasma APA is based on measuring and comparing the indices of plasma CL induced by hydrogen peroxide and spontaneous plasma CL (Ind/Sp $\mathrm{CL}$ ). The calculated parameter of the ratio is a value inversely proportional to plasma APA. The lower this ratio is, the higher APA, and vice versa.

The obtained data were statistically processed using Microsoft Excel software and statistical data analysis package Statistica 8.0 for Windows (StaSoft Inc., USA) and SPSS 15.0. Differences were regarded as statistically significant if $p<0.05$. Quantitative variables were tested for normality of distribution using the Shapiro-Wilk criterion. The obtained findings were evaluated using the following methods of statistical analysis: Pearson's chi-square test (contingency table analysis), Student's t-test and Newman-Keuls criterion for multiple comparisons. Independent non-parametric samples were analysed using Mann-Witney test, whereas for multiple comparisons we used the Kraskell-Wallis criterion. Dependent non-parametric samples were analysed using the Wilcoxon criterion, with multiple comparison performed by means of Friedman's criterion.

\section{RESULTS}

The values of the GROSL (PICLb and PICLs), LPO (blood plasma MDA) and plasma APA (plasma induced-tospontaneous CL ratio) are shown in Table 1.

Table 1. PICLb $\left(\mathrm{mV} / \mathrm{s} \times 10^{6}\right.$ leukocytes $)$, PICLs $\left(\mathrm{mV} / \mathrm{s} \times 10^{6}\right.$ leukocytes $)$, blood plasma $\mathrm{MDA}(\mu \mathrm{mol} / \mathrm{L})$ and plasma induced-to-spontaneous $C L$ ratio in healthy donors

\begin{tabular}{|c|c|c|c|c|}
\hline & PICLb & PICLs & Plasma MDA & $\begin{array}{c}\text { Plasma induced-to- } \\
\text { spontaneous CL } \\
\text { ratio }\end{array}$ \\
\hline Healthy donors & $67.56 \pm 5.23$ & $448.61 \pm 33.56$ & $3.21 \pm 0.15$ & $2.76 \pm 0.14$ \\
\hline
\end{tabular}

The results of studying PICLb in healthy donors and patients with CGP in the phase of exacerbation and remission are shown in Fig. 1. 


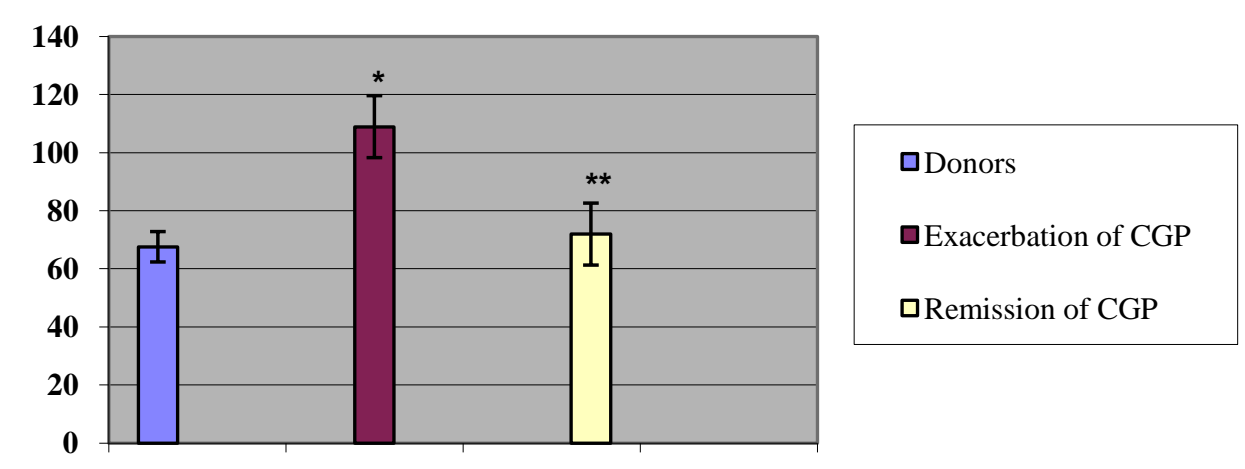

Figure 1. PICLb $\left(\mathrm{mV} / \mathrm{s} \times 10^{6}\right.$ leukocytes $)$ in healthy donors and patients with CGP in the phase of exacerbation and remission;

$* \mathrm{p}<0.05$ compared with healthy donors; ** $-\mathrm{p}<0.05$ compared with exacerbation phase.

The average value of PICLb in patients with CGP in the exacerbation phase amounted to $108.90 \pm 10.67 \mathrm{mV} / \mathrm{s} \times 106$ leukocytes, which was 1.6-fold higher than that in donors, $\mathrm{p}<0.05$. The average value of PICLb in patients with CGP in the remission phase amounted to $71.92 \pm 10.67(\mathrm{mV} / \mathrm{s} \times 106$ leukocytes $)$, which was 1.5 -fold less than that in patients in the exacerbation phase $(\mathrm{p}<0.05)$ and non-significantly above the norm.

The results of studying PICLs in healthy donors and patients with CGP in the stage of exacerbation and remission are shown in Fig. 2.

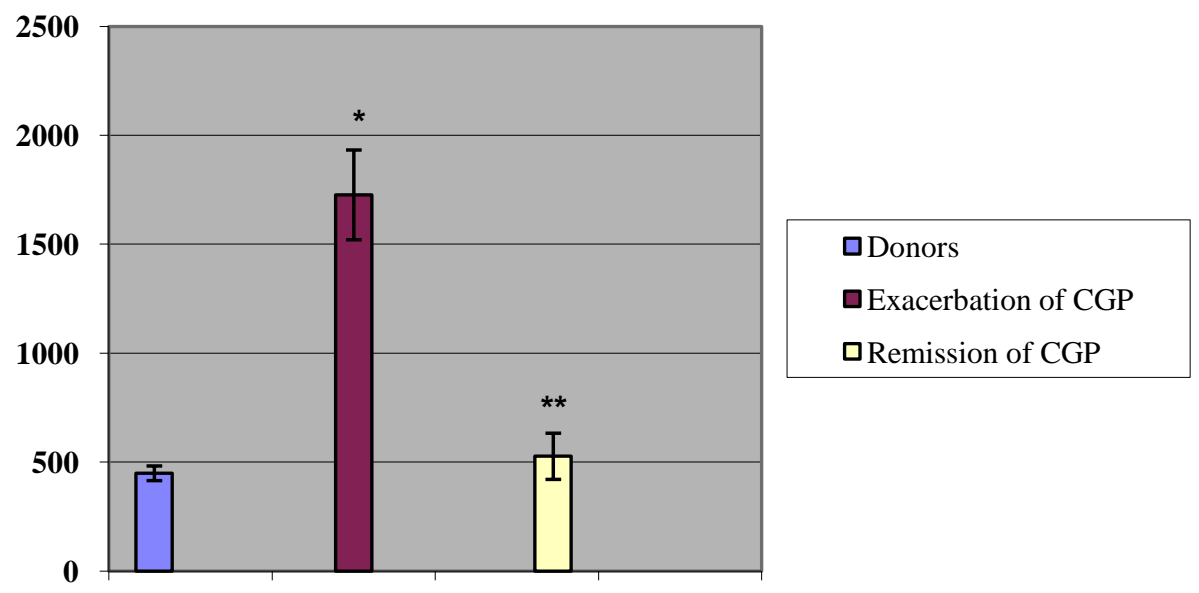

Figure 2. PICLs $\left(\mathrm{mV} / \mathrm{s} \times 10^{6}\right.$ leukocytes $)$ in healthy donors and patients with CGP in the phase of exacerbation and remission;

$* \mathrm{p}<0.05$ compared with healthy donors; $* *-\mathrm{p}<0.05$ compared with exacerbation phase.

The average value of PICLs in patients with CGP in the exacerbation phase amounted to $1726.53 \pm 206.00 \mathrm{mV} / \mathrm{s} \times 106$ leukocytes, which was 3.9-fold higher than that in donors $(\mathrm{p}<0.001)$. The average value of PICLs in patients with CGP in the remission phase amounted to $526.53 \pm 106.00(\mathrm{mV} / \mathrm{s} \times 106$ leukocytes), which was 3.3 times less than in patients in exacerbation phase $(\mathrm{p}<0.05)$ and non-significantly above higher than the norm.

The results of studying blood plasma MDA in healthy donors and patients with CGP in the phase of exacerbation and remission are shown in Fig. 3. 


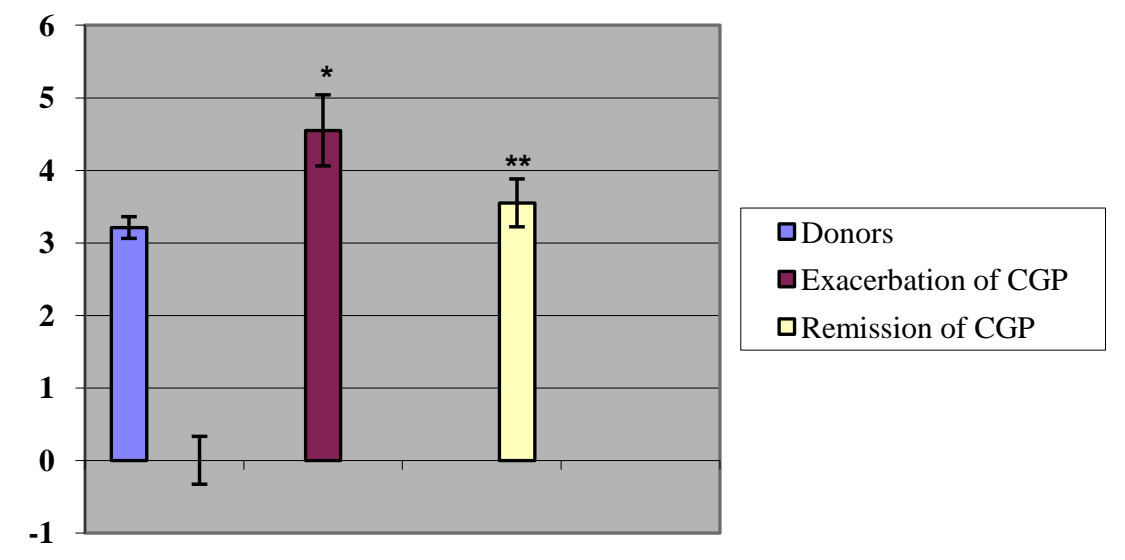

Figure 3. Blood plasma MDA $(\mu \mathrm{mol} / \mathrm{L})$ in healthy donors and patients with CGP in the phase of exacerbation and remission;

$* \mathrm{p}<0.05$ compared with healthy donors; ** $-\mathrm{p}<0.05$ compared with exacerbation phase.

Averagely, blood plasma MDA in with CGP in the exacerbation phase amounted to $4.55 \pm 0.43 \mu \mathrm{mol} / \mathrm{L}$, which was 1.4 times higher than blood plasma MDA in donors $(\mathrm{p}<0.05)$. Blood plasma MDA in remission-phase CGP patients averaged $3.55 \pm 0.33$ $\mu \mathrm{mol} / \mathrm{L}$ which was 1.3 times less than in exacerbation-phase CGP patients $(\mathrm{p}<0.05)$ and non-significantly above the norm.

The results of studying the value of the plasma induced-to-spontaneous CL ratio in donors and patients with CGP in the exacerbation and remission phase are shown in Figure 4.

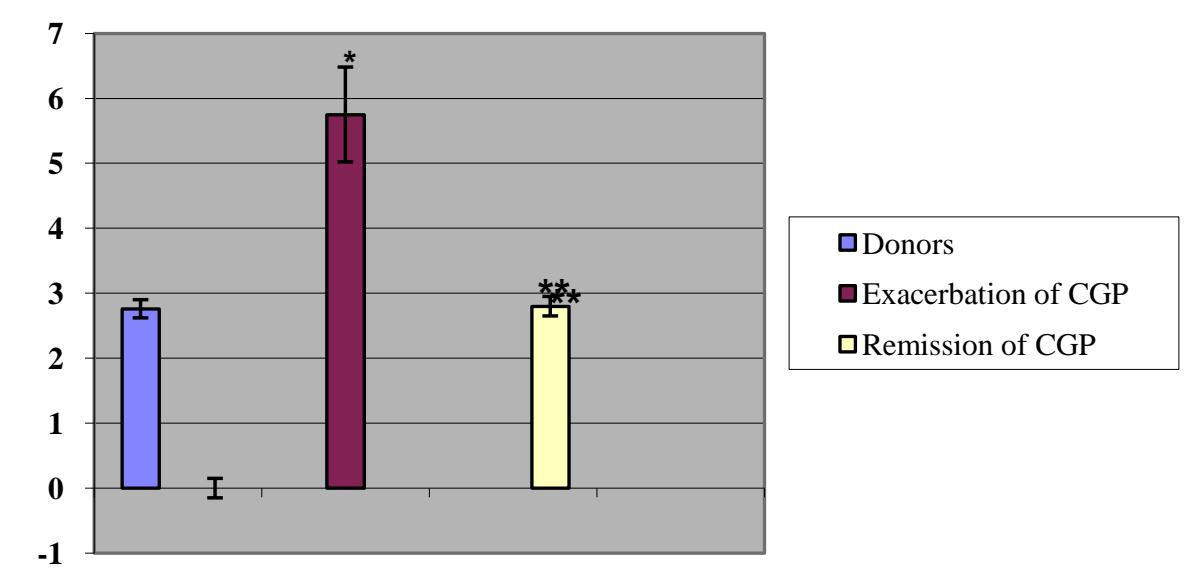

Figure 4. Blood plasma induced-to-spontaneous CL ratio in healthy donors and patients with CGP in the phase of exacerbation and remission;

$* \mathrm{p}<0.05$ compared with healthy donors; $* *-\mathrm{p}<0.05$ compared with exacerbation phase.

The average value of the blood plasma induced-tospontaneous CL ratio in exacerbation-phase CGP patients amounted to $5.75 \pm 0.7$, which was 2.1 times higher than that in donors $(p<0.05)$. The value of the plasma induced-tospontaneous CL ratio in patients with remission-phase CGP averaged $2.80 \pm 1.5$, which was 2.1 times less than in patients in the exacerbation phase $(\mathrm{p}<0.05)$ and non-significantly above the norm.

Analyzing and generalizing the above described data made it possible to draw a conclusion that patients with exacerbation-phase CGP were found to have: a) a natural significant increase in both basal and stimulated PICL compared with healthy donors; $b$ ) increased blood plasma MDA as compared with that in healthy donors $(\mathrm{p}<0.05)$; $\mathrm{c})$ a significant decrease in plasma APA compared with healthy donors $(\mathrm{p}<0.05)$.

Patients with remission-phase CGP as compared with the exacerbation phase were found to have the following:

a) a regular, significant decrease in both basal and stimulated GROSL;

b) a significant decrease in blood plasma MDA; 
c) a significant enhancement of plasma APA;

d) all parameters remained above the norm; however, $\mathrm{p}>0.05$.
Taking into consideration a presumptive pathogenetic role of ROS and LPO in the development of CGP, we found it feasible to examine the parameters of GROSL, plasma LPO and APA in patients with a mild, moderate and severe course of the disease (Figures 5, 6 and 7).

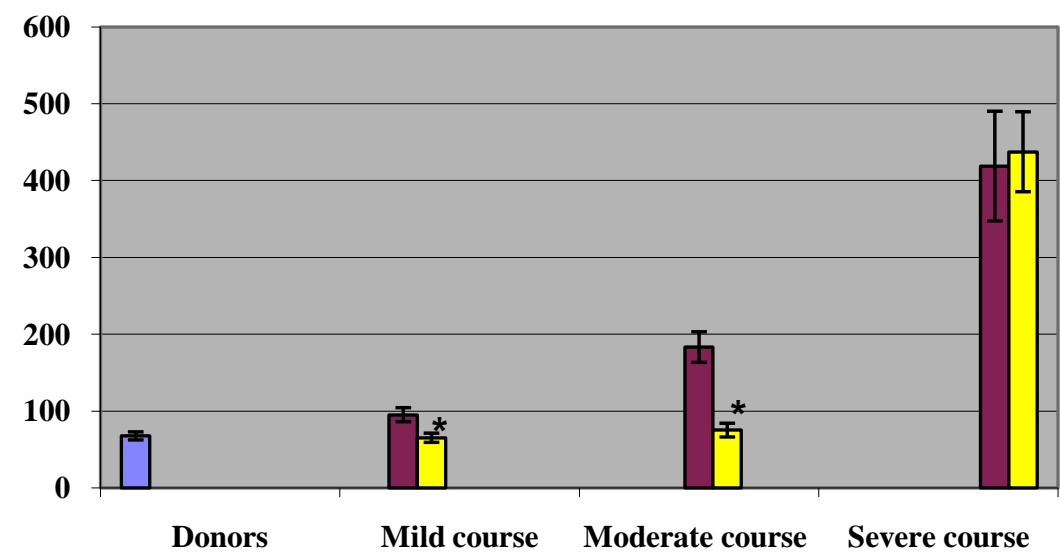

Figure 5. PICLb $\left(\mathrm{mV} / \mathrm{s} \times 10^{6}\right.$ leukocytes $)$ in patients presenting with mild $(n=9)$, moderate $(n=15)$ and severe $(n=4)$ course and treated by $A O$; - prior to the treatment, $\square$ - after the treatment; * $\mathrm{p}<0.05$ compared with the exacerbation phase.

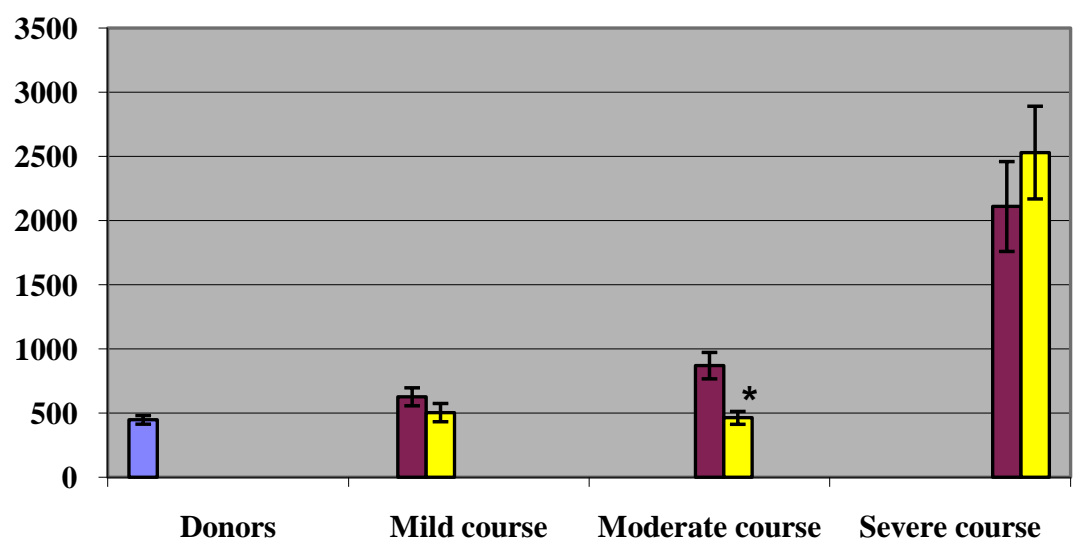

Figure 6. PICLs $\left(\mathrm{mV} / \mathrm{s} \times 10^{6}\right.$ leukocytes $)$ in patients presenting with mild $(n=6)$, moderate $(n=10)$ and severe $(n=4)$ course and treated by $A O$; - prior to the treatment, $\square$ - after the treatment; * $\mathrm{p}<0.05$ compared with the exacerbation phase. 


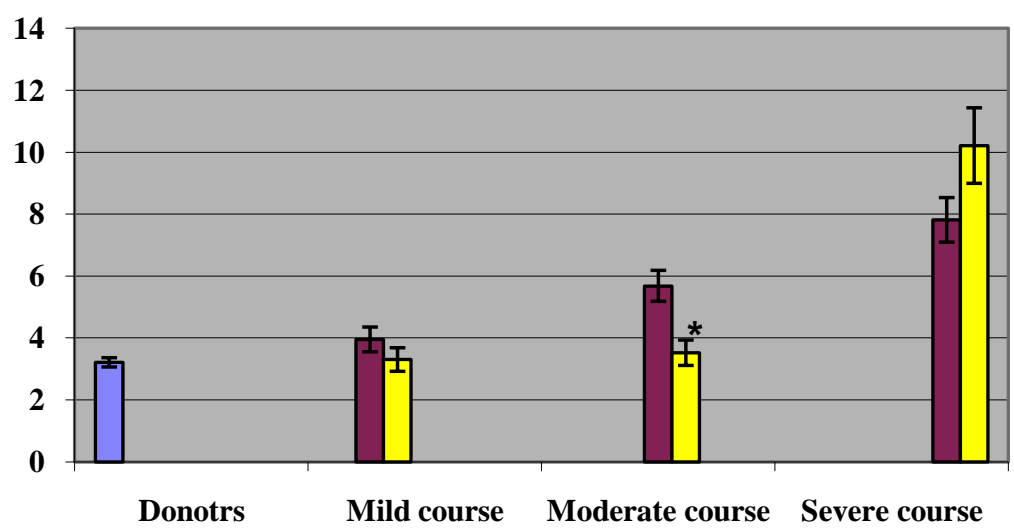

Figure 7. Blood plasma MDA ( $\mu \mathrm{mol} / \mathrm{L})$ in patients presenting with a mild $(n=9)$, moderate $(n=15)$ and severe $(n=4)$ course and receiving treatment with $A O$;

$\square$ - prior to the treatment, $\square$ - after the treatment; $* \mathrm{p}<0.05$ compared with the exacerbation phase.

The PICLb in patients with a mild course of the disease $(n=24)$ averagely amounted to $94.58 \pm 18.77 \mathrm{mV} / \mathrm{s} \times 106$ leukocytes, which was 1.4-fold higher than that in donors (however $\mathrm{p}>0.05$ ); the PICLs averaged $455.87 \pm 57.98 \mathrm{mV} / \mathrm{s} \times 106$ leukocytes, which practically did not differ from that in donors $(\mathrm{p}>0.05)$

Blood plasma MDA in patients with mild CGP $(n=24)$ averagely amounted to $3.85 \pm 0.26 \mu \mathrm{mol} / \mathrm{L}$ which was 1.2 times higher than that in donors $(\mathrm{p}<0.05)$.

The blood plasma induced-to-spontaneous CL ratio in patients with mild CGP $(n=24)$ averagely amounted to $2.82 \pm 0.17$, not virtually differing from that in donors, $p>0.05$.

Hence, patients with mild CGP were found to have a significant elevation of only blood plasma MDA.

The value of PICLb in patients with moderate CGP $(n=35)$ averagely amounted to $175.66 \pm 22.76 \mathrm{mV} / \mathrm{s} \times 106$ leukocytes, thus exceeding 2.6-fold the average PICLb in donors $(\mathrm{p}<0.001)$; the PICLs averaged $852.36 \pm 98.22 \mathrm{mV} / \mathrm{s} \times 106 \mathrm{leu}-$ kocytes, thus exceeding 1.9-fold the PICLs in donors $(\mathrm{p}<0.001)$.

Blood plasma MDA in patients with moderate CGP $(n=35)$ averagely amounted to $4.50 \pm 0.32 \mu \mathrm{mol} / \mathrm{L}$, thus exceeding 1.4 fold the average blood plasma MDA in donors $(\mathrm{p}<0.001)$.

The value of the plasma induced-to-spontaneous CL ratio in patients with moderate CGP $(n=35)$ averagely amounted to $3.86 \pm 0.28$, exceeding 1.4 -fold that in donors $(\mathrm{p}<0.05)$.

Hence, patients with a moderate course of the disease demonstrated a significant increase in both basal and stimulated GROSL, as well as blood plasma MDA and a decrease in plasma APA.
The value of PICLb in patients with severe CGP $(n=13)$ averagely amounted to $445.90 \pm 54.00 \mathrm{mV} / \mathrm{s} \times 106$ leukocytes, which was 6.6-fold higher than that in donors $(\mathrm{p}<0.001)$. the value of PICLb averagely amounted to $2108.47 \pm 317.78$ $\mathrm{mV} / \mathrm{s} \times 106$ leukocytes, which was 4.7 times higher than that in donors $(\mathrm{p}<0.001)$.

Blood plasma MDA in patients with severe CGP $(n=13)$ averagely amounted to $7.38 \pm 0.82 \mu \mathrm{mol} / \mathrm{L}$, which was 2.3 times higher than that in donors $(\mathrm{p}<0.001)$.

The value of the plasma induced-to-spontaneous CL ratio in patients with severe CGP $(n=13)$ averagely amounted to $5.24 \pm 0.68$, thus being 1.9 -fold higher than that in donors $(\mathrm{p}<0.05)$.

Hence, patients with a severe course in the exacerbation phase demonstrated a significant increase in both basal and stimulated GROSL, blood plasma MDA and a decrease in plasma APA.

Comparing the CL parameters of GROSL in various severity of CGP, the following differenced were detected: a) between PICLb and PICLs in patients with mild CGP on the one hand, and patients with moderate and severe CGP on the other, in favour of an increase in the latter $(\mathrm{p}<0.05$ for all parameters) and between PICLb and PICLs in patients with moderate and severe course in favour of the latter $(\mathrm{p}<0.05$ for both parameters); b) patients with moderate and severe CGP had increased blood plasma MDA as compared with patients with mild CGP $(p<0.05$ and $p<0.05)$ and in patients with severe CGP it was also higher than in patients with moderate CGP $(\mathrm{p}<0.05)$; c) plasma APA was significantly lower in patients with severe CGP as compared with patients with mild-tomoderate CGP $(p<0.05$ and $p<0.05$, respectively). 
We also studied peculiarities of situational and personal

CGP, depending on the disease severity (Table 2). anxiety, as well as depression, once present in patients with

Table 2. Parameters of anxiety and depression in mild, moderate and severe periodontitis according to the findings of the Spielberger's test

\begin{tabular}{|c|c|c|c|}
\hline Severity of periodontitis & \multicolumn{1}{|c|}{$\begin{array}{c}\text { Situational } \\
\text { anxiety }\end{array}$} & $\begin{array}{c}\text { Personal } \\
\text { anxiety }\end{array}$ & Depression \\
\hline Control group & $18.1 \pm 3.9$ & $21.4 \pm 5.4$ & $4.2 \pm 1.3$ \\
\hline Mild & $33.8 \pm 3.6^{*}$ & $46.1 \pm 3.6^{*}$ & $13.1 \pm 2.4^{*}$ \\
\hline before treatment & $20.5 \pm 2.8^{\# \#}$ & $29.1 \pm 3.2^{\# \#}$ & $6.2 \pm 0.8^{\# \#}$ \\
\hline after treatment & & & $16.6 \pm 4.8^{*}$ \\
\hline Moderate & $39.8 \pm 2.7^{*}$ & $53.4 \pm 4.0 *$ & $10.4 \pm 3.0^{*}$ \\
\hline before treatment & $27.4 \pm 2.9^{\# \#}$ & $34.4 \pm 4.2 * \# \#$ & \\
\hline after treatment & & & $19.2 \pm 4.4^{*}$ \\
\hline Severe & $49.9 \pm 5.0^{* * *}$ & $68.7 \pm 5.1 * * * \#$ & $24.6 \pm 5.1^{* * * *}$ \\
\hline before treatment & $55.9 \pm 5.1^{* * * \#}$ & $78.5 \pm 7.2^{* * * *}$ & \\
\hline after treatment & & & \\
\hline
\end{tabular}

Designations: $*$ - $\mathrm{p}<0.05$ as compared with the control group;

$* *$ - $\mathrm{p}<0.05$ as compared with mild course;

\# - $\mathrm{p}<0.05$ as compared with moderate course;

\#\# - $\mathrm{p}<0.05$ as compared with patients before treatment of the respective groups.

It was revealed that the increased severity of CGP was associated with elevations in both situational anxiety and personal anxiety, as well as depression. In patients with severe CGP, situational and personality anxiety were 1.5 -fold higher than in patients with mild CGP $(\mathrm{p}<0.05)$, and depression was also 1.5-fold higher; however, $\mathrm{p}>0.05$.

Having detected in previous studies that after the carried out treatment there remained some patients showing neither clinical effect nor dynamics of alterations in the parameters of free-radical processes, we found it feasible to explore the effect of AO therapy on patients with CGP depending on severity.

Patients with mild and moderate CGP under the influence of AO therapy demonstrated a decrease in PICLb 1.5- and 2.4fold, respectively $(p<0.05$ and $p<0.05$, respectively, Fig. 5). However, quite opposite results were obtained in patients with severe CGP. PICLb in these patients after the carried out AO therapy increased 1.1-fold ( $>>0.05)$. Thus, AO therapy in patients with severe CGP was accompanied and followed by increased PICLb.
Similar results were obtained in studying PICLs and blood plasma MDA under the effect of AO therapy (Figures 6 and 7). In all patients, AO therapy according to these indices also turned out to be ineffective.

Besides, patients with severe CGP had no clinical improvement. The signs of inflammation failed to regress; the depth of the periodontal pocket did not change, with no dynamics of dental scales either.

Hence, antioxidant therapy in patients with severe CGP resulted in neither clinical improvement nor a decrease in freeradical processes.

Simultaneously, patients with severe CGP after AO treatment were found to have elevated situational and personality anxiety, deteriorated depression, unlike patients with mild-tomoderate CGP in whom this symptomatology virtually disappeared.

Therefore, we came to a conclusion that these patients should be subjected to surgical treatment. The latter included 
curettage of periodontal pockets, periodontal flap operations, and tooth extraction.

In patients with a severe course of periodontitis after surgical manipulations, the parameter in Hounsfield units increased gradually, on days 14,30 and 90 averagely 1.3-, 2.4and 3.2-fold, respectively.

\section{CONFLICTS OF INTEREST}

The authors declare that there is no conflict of interest regarding the publication of this article.

\section{REFERENCES}

1. Eke PI, Thornton-Evans GO, Wei L et al. Periodontitis in US Adults: National Health and Nutrition Examination Survey 2009-2014. J Am Dent Assoc. 2018;149(7):576588.e6.

2. Frencken JE, Sharma P, Stenhouse L et al. Global epidemiology of dental caries and severe periodontitis - a comprehensive review. J Clin Periodontol. 2017;44 Suppl 18:94-105.

3. Darveau RP. Periodontitis: a polymicrobial disruption of host homeostasis. Nature Rev. Microbiol.2010;8:481490.

4. Papapanou PN. In: Oral Microbiology and Immunology. Lamont RJ, Hajishengallis G, Jenkinson H, editors. ASM Press; Washington DC: 2014. pp. 251-271.

5. Saulin M., Bolevich S., Silina E., Orlova A., Raicevic N., Vorobiev S., Bolevich St., Sinelnikova T. Influence of the local and systemic oxidative stress on periodontitis: role of antioxidant therapy. 2018:19(4): 365-372.

6. Abusleme L, et al. The subgingival microbiome in health and periodontitis and its relationship with community biomass and inflammation. ISME J. 2013;7:1016-1025.
The findings of the analysis of dental cone beam computed tomography with the help of determining bone tissue density in Hounsfield units suggested that bone mineral density increased faster after surgical methods of treatment in patients with severe chronic generalized periodontitis. This is an indirect sign of success of carried out manipulations.

\section{ACKNOWLEDGMENTS}

This work was supported by the "Russian Academic Excellence Project 5-100".

7. Rosier BT, de Jager M, Zaura E, Krom BP. Historical and contemporary hypotheses on the development of oral diseases: are we there yet? Front Cell Infect. Microbiol. 2014;4

8. Bartosz G. Reactive oxygen species: destroyers or messengers? Biochemical Pharmacology. 2009;77(8):13031315. doi: 10.1016/j.bcp.2008.11.009.

9. Halliwell B., Gutteridge J.M.C. 4th ed. Oxford University Press; Oxford: 2007. Free Radicals in Biology and Medicine.

10. Droge W. (2002). Free radicals in the physiological control of cell function. Physiol. Rev. 82, 47-95. 10.1152/physrev.00018.2001

11. Bolevich S, Kogan AH, Zivkovic V, Djuric D, Novikov AA, Vorobyev SI, Jakovljevic V. Protective role of carbon dioxide $(\mathrm{CO} 2)$ in generation of reactive oxygen species. Mol Cell Biochem. 2016 Jan;411(1-2):317-30.

12. Chapple I. L., Matthews J. B. (2007). The role of reactive oxygen and antioxidant species in periodontal tissue destruction. Periodontol 43, 160-232.

13. Genco RJ, Van Dyke TE. Prevention: Reducing the risk of CVD in patients with periodontitis. Nature Rev. Cardiol. 2010;7:479-480. 
$\$$ sciendo 